\title{
Cass R. Sunstein: Choosing Not to Choose. Understanding the Value of Choice
}

\author{
Oxford University Press, Oxford-New York, 2015, 220 o.
}

Cass Sunstein, a Harvard jogászprofesszora Richard Thalerrel közösen írt, Nudge címü könyve és a kérdésben végzett önálló kutatásai révén is jelentős alakja a viselkedési közgazdaságtan közpolitikára való alkalmazásának (Thaler-Sunstein [2011]). Jelen könyvében egy olyan témát bont ki, amiről már a Nudge-ban is szó volt: az alapértelmezett beállítások mint viselkedésszabályozó eszközök szerepét vizsgálja az üzleti döntésektől a leghétköznapibbakig. Alapértelmezett (default) beállítások alkalmazásán olyan döntéstervezési eszköztárat értünk, amely bizonyos döntési helyzetekben meghatározza az automatikusan választható lehetőség(ek)et. A döntéshozónak csak akkor kell aktívan döntenie, ha az alapértelmezett helyett mást választ - ugyanúgy, mint amikor nincs is ilyen beállítás. Sunstein a könyvben arra keresi a választ, milyen körülmények között vezethet hatékony, illetve kevésbé hatékony eredményre az alapértelmezett beállítások alkalmazása, és ami még fontosabb, milyen jellegü alapértelmezett beállításokat és kinek kellene megszabni. A szerző a könyvben sorra veszi nemcsak az alapértelmezett beállítások előnyeit, hanem a lehetséges hátrányait is. Végül Sunstein levonja a maga tanulságait és prognózisokat fogalmaz meg arra vonatkozóan is, hogy a jövőben milyen alapértelmezett beállításokkal fognak élni az egyének.

\section{Hagyományos ösztönzők versus alapértelmezett beállítások}

Sunstein részben a hagyományos közgazdaságtani felfogással szemben fogalmazza meg fö téziseit. A közgazdaságtan hagyományos pozitív felfogása szerint az egyének racionális döntéseket hoznak. Ebből fakadóan a közgazdaságtant (és később a jóléti közgazdaságtant) már Adam Smithtől kezdődően egyfajta „liberális”, antipaternalista normatív szemléletmód jellemezte. Sunstein a viselkedési közgazdászok szokásos bírálatának veti alá ezeket a feltevéseket. A szerző szerint például a pénzügyi ösztönzőknél gyakran hatásosabbak lehetnek az egyszerủ alapértelmezett szabályok, és ez azért van, mert az ösztönzők müködéséhez szükség van arra, hogy azokat az alanyok észrevegyék, míg az alapértelmezett szabályok éppen azért lehetnek

A kézirat első változata 2016. február 22-én érkezett szerkesztőségünkbe.

DOI: http://dx.doi.org/10.18414/KSZ.2016.7-8.889 
hatásosak, mert kifejezetten arra alapoznak, hogy az egyének gyakran nem veszik észre választási halmazuk módosulását.

Felmerül azonban a kérdés: ha az alapértelmezett beállítások a hagyományos ösztönzőknél hatásosabbak lehetnek, igaz-e, hogy hatékonyabbak is? A standard jóléti közgazdaságtan szemszögéből nézve ugyanis nem az a cél, hogy adott tevékenységből minél kevesebbet vagy minél többet végezzenek az emberek, hanem hogy a társadalmilag optimális szintet válasszák ki. Sunstein nem nyújt kellően meggyőző érveket arra nézve, hogy az alapértelmezett beállítások a hagyományos ösztönzőknél (elsősorban a pigou-i adóknál és támogatásoknál) esetenként nemcsak hatásosabbak, de a fenti cél szempontjából hatékonyabbak is. Egy példával élve, legyen adott kétféle megtakarítási terv egy nyugdíj-takarékossági programban: egy „alacsony” és egy „magas” szintű. Ha a túl alacsony szintű megtakarítások miatt aggódunk, és erre válaszul a „magas” tervet állítjuk be alapértelmezettként, könnyen lehet, hogy az új egyensúlyban nem túl kevés, hanem túl sok megtakarítás halmozódik fel.

\section{Hogyan müködnek az alapértelmezett beállítások?}

Sunstein a döntéshozatali költségekből indul ki annak tárgyalásakor, hogy miért lehet számottevő hatásuk az alapértelmezett beállításoknak, illetve hogy miért lehet pozitív szerepük. A döntéshozatal költségei több tényezőből tevődhetnek össze. Elöször is a döntéshozóknak bizonyos esetekben nincsenek jól meghatározott preferenciáik, ekkor maguknak a preferenciáknak a feltárása költségekkel jár. Költségei vannak továbbá a választási lehetőségek keresésének is, valamint - ami a legérdekesebb - a döntéshozatali helyzet önmagában pszichikai költségekkel járhat. Az alapértelmezett szabályok ezeket a költségeket csökkenthetik azzal, hogy meghatároznak egy alap döntési lehetőséget, amit a döntéshozó automatikusan elfogadhat akkor, ha nem kíván más lehetőséget választani.

A döntéshozatali költségek mértéke azonban nem az egyedüli szempont, amelyet figyelembe kell venni. Kérdés az is, hogy az alapértelmezett beállítások meghatározói (vagyis a „döntéstervezők”) mennyire képesek jó alapértelmezett beállításokat kialakítani. Ez függ a döntéstervezö ösztönzőitől és informáltságától, saját kognitív korlátaitól, valamint attól is, hogy mekkora mértékben sokfélék a döntéshozók, tehát adott esetben mennyire lehet egy kaptafára beállítani az alaphelyzetet. A „modell” komparatív statikája egyszerü: az egyén döntéshozatali költségeinek növekedésével nő az alapértelmezett beállítások hasznossága, az alapértelmezett beállítások „hibaköltségeinek" növekedésével pedig csökken.

\section{Ösztönzők-e az alapértelmezett beállítások?}

Sunstein az alapértelmezett beállításokat szembeállítja a közgazdaságtanban hagyományosan hangsúlyosabb ösztönzőkkel. Nem egyértelmü ugyanakkor, hogy ez a megkülönböztetés jogos-e. Ahogyan Sunstein is hangsúlyozza, egy alapértelmezett 
beállítás jelenléte költségesebbé teszi bármely más alternatíva kiválasztását - az alapértelmezett beállításokkal éppen azt a kognitív költségekre való érzékenységet lehet kihasználni, ami miatt eleve szükség lehet rájuk. Sunstein ezzel konzisztens módon több helyen is egyfajta „adóként” utal az alapértelmezett beállításokra. Ha viszont az alapértelmezett beállításokkal más alternatívákra egyfajta adót vetünk ki, akkor ugyanúgy torzíthatjuk a döntéshozók magatartását, mint a hagyományos ösztönzőkkel. Az alapértelmezett beállítások ennek megfelelően lehetnek ,jók” és „rosszak” is, attól függően, hogy a magatartást milyen irányban befolyásolják.

A szerző azonban ezzel kapcsolatban elhanyagol egy szempontot. Az alapértelmezett beállításokkal egyfajta „eröfeszítés adót” vetünk ki a többi lehetőség választására, azonban emellett elképzelhető, hogy az egyén „pszichikai adót” is „fizet”, amikor el kíván térni az alapértelmezett beállítástól. Ha például - a könyv egyik példájával élve - egy taxitársaság alapértelmezett borravaló-opciókat ajánl fel a fogyasztóknak, a fogyasztó az azoktól való eltéréskor kellemetlenül érezheti magát, elsősorban akkor, ha „lefelé” tér el. Ez a szempont azért fontos, mert - ahogyan azt Glaeser [2005] és Glaeser-Újhelyi [2010] megmutatták - a valamilyen szempontból nem optimálisnak tekintett magatartás pénzbeli adóztatása első megközelítésben hatékonyabb, mint társadalmi nyomás révén vagy más módon „pszichikai adók” kivetése az adott tevékenységre, mivel előbbi esetben a tevékenységet végző egyén veszteségének egy részéből adóbevétel keletkezik, az utóbbi esetben viszont nem.

\section{„Jó” és „rossz” alapértelmezett beállítások}

Sunstein könyvében részletesen kitér a „jó” és „rossz” alapértelmezett beállítások már érintett kérdésére. Végig elsősorban a kormányzati alapértelmezett beállításokkal foglalkozik, a piaciakkal kevésbé, ugyanakkor előbbieket párhuzamba állítja az utóbbiakkal. Kiemeli, hogy a verseny és a profitmotívum arra késztetheti a magán(vagy piaci) döntéstervezőket, hogy olyan alapértelmezett beállításokat válasszanak, amelyek maximalizálják a fogyasztói többletet. A politikai piacon a szerző szerint hasonló mechanizmus vezethet el hatékony alapértelmezett beállítások kialakulásához (leginkább a szavazókért folytatott versenyben).

Ez az érvelés azonban több okból is problematikus, és a kormányzati szektor szereplöinek más - és összességében valószínüleg rosszabb - ösztönzőik lehetnek az alapértelmezett beállítások kiválasztására: elöször is, a politikai piacon nincsen profitérdekeltség, ugyanakkor másfajta erős ösztönzők jelen vannak, amelyek nem feltétlenül a hatékony döntéshozás javára billentik a mérleget: erős az ösztönző például a rövid távú szavazatmaximalizálásra, a hatalom megszerzésére és megtartására. Mondhatnánk természetesen, mint ahogyan azt a szerző említi, hogy a pártok közötti verseny a piaci versenyhez hasonlóan fegyelmezheti a politikai szereplőket - vagy említhetnénk akár az érdekcsoportok versenyét is (Becker [1983]). Sunstein azonban nem említi az egyik legfontosabb közösségi döntési problémát, a szavazók tájékozatlanságát a racionális döntések terén, ami kevésbé költségessé teszi a félrevezetést a politikában, mint a magánpiacon. 
A fentieken kívül a legalapvetőbb kérdés talán az, hogy egyáltalán milyen alapon különíthetjük el a „jó" alapértelmezett beállításokat a „rosszaktól”. Sunstein normatív kritériumként az informált választó fogalmát javasolja. Ez a megközelítés szükségképpen hipotetikus, hiszen azt a kérdést teszi fel, mit választott volna az adott helyzetben egy megfelelően informált egyén. Tehát az egyéni választást adott esetekben a szerző úgy kívánja „szimulálni” alapértelmezett beállítások segítségével, hogy megpróbálja a végső döntést a lehető legjobban megfeleltetni az egyén valódi preferenciáinak. Egy ilyen szempont azonban visszavihet minket a kinyilvánított preferenciák fogalmához, de a viselkedési eredmények gyakran éppen azt mutatják meg, hogy az egyének kinyilvánított preferenciái nem mindig alkalmasak arra, hogy a jóléti elemzések alapjául szolgáljanak.

Sunstein nem oldja fel kellöképpen ezeket az ellentmondásokat, mindenesetre megpróbál néhány támpontot adni, ami többé-kevésbé biztató: az egyes alapértelmezett beállítások bevezetése elött például meg lehetne közvetlenül figyelni, hogy az „aktív választás” periódusában hogyan döntenek valójában az egyének. A tárgyalásból azonban önmagában nem teljesen világos, hogy ezt hogyan képzelhetjük el. Az alapértelmezett beállítások célja éppen az olyan döntés elösegítése, amely azok hiányában nem, vagy kisebb gyakorisággal születne meg a magas döntéshozatali költségek miatt. Amiben ténylegesen segíthet ez a módszer, az talán leginkább azon esetek kiszürése, amelyekben nincs szükség alapértelmezett beállításokra. A megfelelö alapértelmezett beállítások kiválasztásának kérdésében összességében nem jut megnyugtató konklúzióra a szerző, és maga is említi azt az aggodalmat, hogy jobb támpontok híján az alapértelmezett beállításokat arra használhatják a döntéstervezők, hogy saját preferenciáikat „erőltessék rá” a döntéshozókra.

\section{Alapértelmezett beállítások és paternalizmus - "choosing not to choose"}

A viselkedési beavatkozásokat a legtöbben azért bírálják, mert híveik valamilyen mértékben paternalista érvrendszert használnak, és paternalista - igaz, „puha” vagy „libertárius” paternalista - beavatkozásokat javasolnak.

Sunstein az eddigi vitákat egy új felvetéssel próbálja felélénkíteni: nem azok-e inkább a paternalisták, akik minden áron aktív döntésre szeretnék bírni az embereket. Hiszen számos esetben, ahogyan azt a könyv dokumentálja, az egyének nem szeretnének aktív döntést hozni, mivel ez számukra túl költséges. Sunstein felvázolja az alapértelmezett beállítások politikájának egy nem paternalista változatát, amit egyszerüsitett aktív választásnak nevez, és ami a könyv legeredetibb gondolata: az egyének dönthessenek arról, hogy szeretnének-e dönteni!

Tegyük fel, hogy egy egyén tisztában van azzal, hogy ha aktív döntést vállal, annak milyen költségei vannak, de azzal is, hogy ha erröl lemond, akkor a politikusok vagy a vállalatok „kezébe” adja a döntést. Az egyén e döntéshozatali (illetve hibázási) költségek minimalizálására törekszik, és ennek megfelelöen választja meg azokat az eseteket, amikor meghagyja magának az aktív választás lehetőségét, és azokat az eseteket, amikor valamilyen alapértelmezett beállítást „rendel” magának. Az egyik legfontosabb 
kérdés ebben az esetben az, mennyire bíznak meg a döntéshozók a döntéstervezőkben: ha az egyénnek racionális várakozásai vannak a döntéstervezők viselkedésével kapcsolatban, akkor egy ilyen szabály elég egyértelmüen jólét-maximalizáló lehet.

Mi a helyzet azonban akkor, ha - amint azt a viselkedési közgazdászok hangsúlyozzák - a várakozások nem racionálisak? Sunstein erre is kitér: ekkor indokolt lehet egy olyan paternalizmus, ami nem engedi meg (ellenösztönzi) az „önkéntes paternalizmust”, vagy éppen ellenkezőleg, ösztönzi azt. Tehát a döntés lehetőségéről való döntésnek is vannak költségei, ezért szembesülhet ugyanazokkal a problémákkal, mint a „végső aktív" döntés. Az aktív döntés ösztönzése akkor is indokolt lehet, ha az jelentősen hozzájárul az egyén döntési kompetenciájának fejlődéséhez, és ezt az egyén túlzott rövidlátása miatt nem veszi eléggé figyelembe, illetve ha az egyén fenti metadöntésének pozitív vagy negatív externáliái vannak.

Mindenesetre, bár a vitatott megközelítés nem problémamentes, mindenképpen kreatív és jól ötvözi a hagyományos és a viselkedési közgazdaságtani szemléletet: az egyének hibákat követnek el döntéseik során, de ezzel egy elég racionális döntéshozó tisztában van, és ennek megfelelően a jövőre nézve csökkentheti saját kognitív hiányosságainak költségeit. Kérdés, hogy ezt mikor engedjük meg nekik, és mikor nem. Mikor legyünk „antipaternalista paternalisták”?

\section{Az alapértelmezett beállítások jövője - személyre szabás}

A könyv egyik legérdekesebb fejezetében Sunstein az alapértelmezett beállítások lehetséges jövőbeli fejlődését veszi számba. A legígéretesebb, de talán sokak számára ijesztő fejlemény az lehet, hogy a technológia fejlődésével a személyiségjegyeink és ez alapján a preferenciáink alapján személyre szabott alapértelmezett beállításokat tudunk majd „rendelni” magunk számára. Ez a perszonalizáció egyfelől vonzó lehet abból a szempontból, hogy csökkentheti az alapértelmezett beállítások heterogenitási költségeit, másrészt viszont aggodalmakat ébreszthet sokakban a magánszféra védelme szempontjából.

Személyre szabott alapértelmezett beállítások, amint arra a szerző felhívja a figyelmet, valamilyen („kezdetleges”) formában már ma is müködnek: házasságokban és egyéb szoros kapcsolatokban például a felek a döntések egy részét elvégzik egymás helyett, egymás „megrendelésére”. Továbbá ide sorolhatjuk a vállalatok különböző termékajánlásait is a fogyasztók számára. Ez természetesen a szó szigorú értelmében nem alapértelmezett beállítás. Az alapértelmezett választás továbbra is a „nem vásárlás" marad. De mindig ez lesz majd a helyzet? Lehet, hogy egyszer eljutunk oda, hogy nem egy termék megvásárlásáról, hanem annak nem megvásárlásáról dönthetünk majd? Sunstein ilyen kérdéseket feszeget a könyv e részében.

Cass Sunstein egy tömör és olvasmányos könyvet írt az alapértelmezett beállítások szerepéről és azok alkalmazásának kihívásairól. A könyv nagy erénye, hogy megpróbál választ adni a „puha paternalizmus” és azon belül az alapértelmezett beállítások 
alkalmazásának eddigi kritikáira, igaz - valószínüleg a terjedelmi korlátok miatt -, nem mindig sikerül kielégítő választ adnia e kritikákra. A könyv címében feltett kérdés - choosing not to choose - viszont számos területen alapvető fontosságú. Egyrészt ez a problémakör nem feltétlenül új, és nem csak a modern paternalizmusviták kapcsán kerülhet elő. Bár kétségkívül a technológiai fejlődés a jelenséget új szintre emeli, az emberek a specializáció kezdete óta „rábízzák magukat” mások szakértelmére: az orvos vagy az autószerelő információs előnyben van velünk szemben, azonban mégis bízunk bennük, de gyakran felmerül a kérdés: miért?

A lehetséges válaszok között újra és újra megjelenik a reputációs ösztönzők szerepe, amelyek azonban gyakran erősebbek a piaci, mint a kormányzati döntéshozók esetében. Emiatt is érdemes lett volna a szerzőnek többet elidőznie a magán- és a politikai piacokon jelen lévő ösztönzők és információs előnyök vagy hátrányok elemzésénél. Ehhez kapcsolódik, hogy felhívjuk a figyelmet: a politikai döntések viselkedési közgazdaságtana általában véve is elhanyagolt téma a viselkedési közgazdaságtani szakirodalomban. Sunstein könyve is illusztrálja, hogy szükség van e témakör eddigieknél szisztematikusabb vizsgálatára.

\section{Hivatkozások}

Becker, G. S. [1983]: A Theory of Competiton Among Pressure Groups for Political Influence. Quarterly Journal of Economics, Vol. 98. No. 3. 371-400. o. http://dx.doi. org/10.2307/1886017.

Glaeser, E. L. [2005]: Paternalism and Psychology. NBER Working Paper, 11789. http:// dx.doi.org/10.3386/w11789.

Glaeser, E. L.-Ujhelyi Gergely [2010]: Regulating Misinformation. Journal of Public Economics, Vol. 94. No. 3-4. 247-257. o. http://dx.doi.org/10.1016/j.jpubeco.2010.01.001.

Thaler, R. H.-Sunstein, C. R. [2011]: Nudge. Jobb döntések egészségről, pénzről és boldogságról - a pénzügyi válság után. Manager Kiadó, Budapest.

Isztin Péter

Isztin Péter, a BCE doktoranduszhallgatója (e-mail: isztin.peter@gmail.com). 